\title{
Mad'arská palebná linie pod vrchem Veretyčiv u obce Habura Prvotní výsledky výzkumu bojiště první světové války
}

\section{Hungarian firing line below the Veretyčiv hill near the municipality of Habura First results from the survey of a World War I battlefield}

\author{
Jiří Zubalík / Martin Fojtík / Radim Kapavík / Jakub Těsnohlídek / Martin Vojtas \\ Jan Petřík / Peter Tajkov
}

\begin{abstract}
Abstrakt
Článek představuje výsledky části širšího průzkumu bojiště z první světové války, nacházejícího se u obce Habura na severovýchodním Slovensku. V květnu 1915 byl na této lokalitě uskutečněn útok jednotek 17. honvédského pluku s cílem dobýt ruské pozice na hraničním hřebeni. Na základě prvotních zjištění byl archeologický průzkum soustředěn do prostoru nezalesněné pláně pod hřebenem, kde se nacházela značná koncentrace kovových artefaktů. Byla zvolena systematická detektorová prospekce v polygonové síti s cílem lokalizovat palebné pozice uherských jednotek a určit detaily útoku.
\end{abstract}

\section{Klíčová slova}

první světová válka, východní fronta, detektory kovů, archeologie bojišt', honvédské jednotky

\begin{abstract}
The article presents partial results from a large-scale survey of the World War I battlefield near the municipality of Habura in Northeast Slovakia. In May 1915, military units of the 17th Honvéd Regiment launched an attack with the aim to seize the Russian positions on the border ridge. Subsequent to preliminary reconnaissance, archaeological survey was targeted at the area of an unforested grassland below the ridge, where a distinct concentration of metal artefacts was detected. Systematic detector survey was carried out in a polygon grid to localise firing positions of Hungarian troops and to find out details about the attack.
\end{abstract}

\section{Key words}

World War I, Eastern Front, metal detectors, battlefield archaeology, Honvéd troops 


\section{1. Úvod}

Průzkum bojiště první světové války na vrchu Veretyčiv u obce Habura (okr. Medzilaborce, severovýchodní Slovensko) navazuje na výzkumné aktivity zájemců o archeologii novověkých konfliktů sdružených ve spolku Zákopy.cz, které se doposud soustřed'ovaly především na lokality na vrchu Staviská u obce Stebník (Vojtas 2018; Zubalik et al. 2017a; 2019) a na vrchu Kobyla u obce Výrava (Zubalik et al. 2017b). Průzkum, kterému je věnovaný tento příspěvek, se od předešlých odlišuje - nebyl totiž zaměřen na dokumentaci povrchových reliktů. Jeho cílem bylo ověřit možnost výzkumu průběhu konkrétní útočné operace.

Podobné typy průzkumu nejsou v archeologii moderních konfliktů běžné. Většina prací se soustředuje především na zmíněnou dokumentaci a exkavaci polních fortifikací (případně leteckých krytů apod.), přičemž detektor kovů bývá využíván na lokalizaci hmotné kultury vzhledem k těmto reliktům (např. Gonzáles-Ruibal 2011; Pollard 2014; Rak 2011). Jednou z výjimek je práce Thomase J. Nolana, který za pomocí detektoru a geografických informačních systémů (GIS) byl schopný rekonstruovat průběh legendární hlídky Alvina C. Yorka z 8. října 1918. Americký seržant spolu s několika dalšími příslušníky své čety během ní zajal u Châtel-Chéhéry ve Francii 132 nepřátel (Nolan 2009). Další příklady se spíš váží ke starším obdobím. Průkopnickou prací je průzkum bojiště u Little Bighornu z poloviny 80 . let, který vyvrátil legendu o hrdinné obraně amerických vojáků před indiánskými válečníky (Scott 2005). Dále je možno zmínit např. průzkum bojiště z roku 1690 u řeky Boyne v Irsku (Brady - Byrnes - Cooney O'Sullivan 2007), bojiště americké občanské války u Mine Creek (Lees 1998) či bitvy americké války za nezávislost odehrávající se v roce 1777 u Ridgefieldu (Silliman - Batt 2015). V českém prostředí lze zmínit detektorové prospekce bo- jiště na Bílé Hoře (Bureš - Rytiř 2017), průzkum bojiště u Rozvadova z roku 1621 (Šámal 2018), nebo části bojiště u Náchoda z roku 1866 (Holas 2017).

Průzkum na lokalitě Veretyčiv měl prokázat využitelnost této metody průzkumu i na karpatských bojištích první světové války. V prostoru těsně pod vrcholem se v květnu roku 1915 opevnily jednotky ruské armády, které se následně ocitly pod útokem mad’arských vojáků (viz níže). Detektorová prospekce měla ověřit, zda lze zachytit místo útoku mad’arských vojáků (kteří po sobě nezanechali žádné terénní relikty) na ruské okopy.

Lokalita byla vybrána k výzkumu mad’arskými historiky ze sdružení Nagy Háború. Sdružení se zabývá první světovou válkou a především rolí mad’arských jednotek a vojáků v ní (https:// nagyhaboru.blog.hu/). Průzkum proběhl ve spolupráci s Katedrou teórie a dejín umenia Technické univerzity v Košicích.

\section{Historie lokality}

Boje první světové války se do oblasti Medzilaborců přenesly v polovině listopadu 1914, kdy sem ustoupila rakousko-uherská 3. armáda, pronásledovaná ruskou 8. armádou. Zastavit ruský postup na hlavním karpatském hřebeni se však rakouským jednotkám nepodařilo a do začátku prosince musely ustoupit hluboko na území dnešního Slovenska (ruské síly obsadily Bardejov, Stropkov a Humenné). Odtud na počátku prosince zahájily protiútok, kterým ruské oddíly vytlačily zpět za Karpaty (až k Sanoku); ani při tomto přechodu fronty nevznikly na hlavním karpatském hřebeni žádné dlouhodobé pozice jedné či druhé strany. Teprve po dalším ruském protiútoku na samém sklonku roku 1914, který sem zatlačil oddíly rakouské 3. armády, se fronta na přelomu let 1914 a 1915 ustálila př́mo na hlavním karpatském hřebeni. 


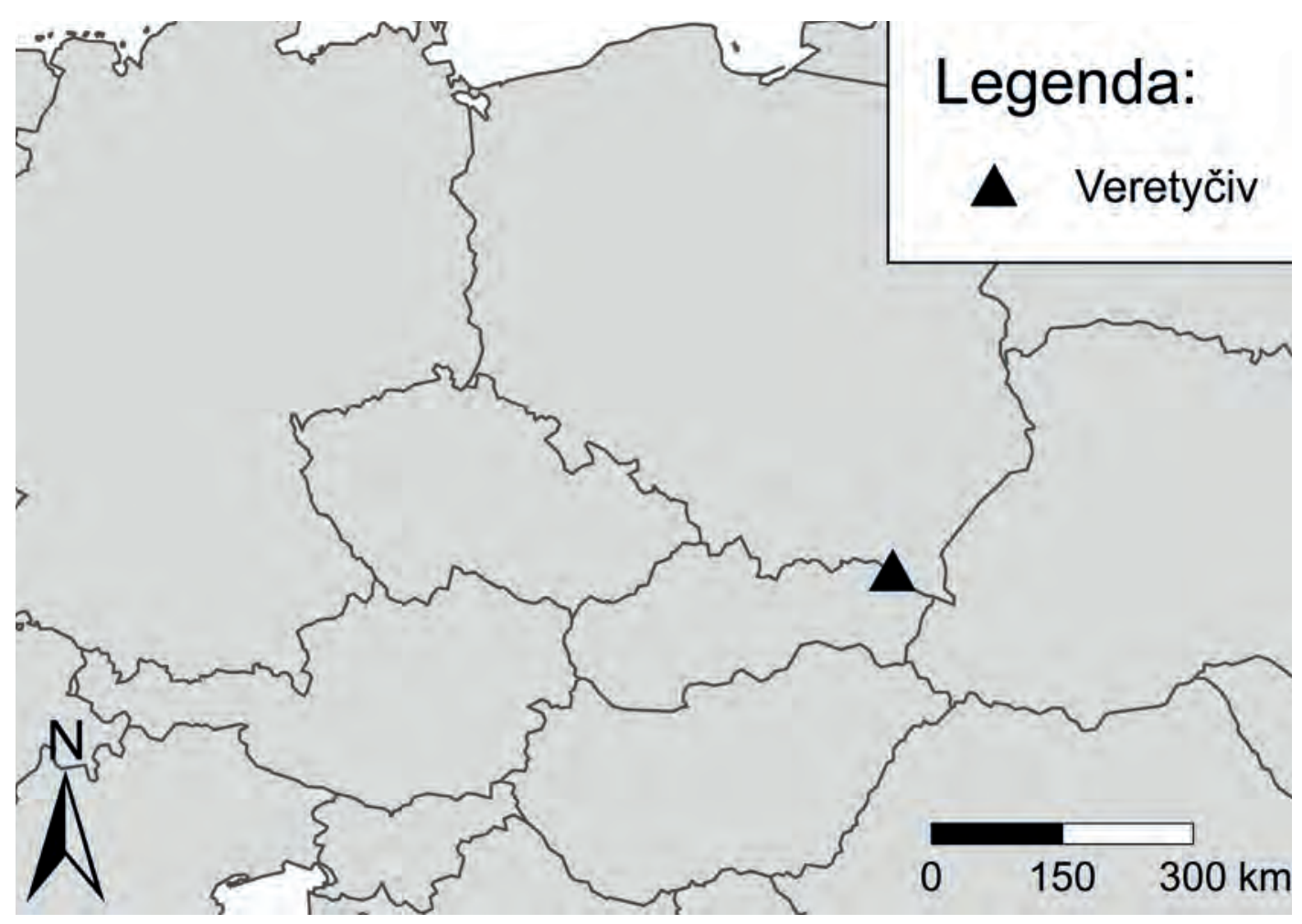

Obr. 1. Mapa Slovenska s vyznačeným vrchem Veretyčiv. Autor: Jiř́ Zubalík. Data: https://ec.europa.eu/eurostat/web/gisco/.

Fig. 1. Map of Slovakia showing the position of the Veretyčiv hill. Author: Jiří Zubalík. Data: https://ec.europa. eu/eurostat/web/gisco/.

Nad obcí Habura byla pak po celý leden 1915 ve statických zákopových pozicích rozmístěna rakousko-uherská 2. pěší divize. $\mathrm{Z}$ těchto pozic byla vytlačena na samém konci měsíce, když ruská 8. armáda prolomila rakouské pozice v Dukelském a Lupkovském průsmyku a nová frontová linie se ustálila o 15-20 km dále na jih (Kriegsarchiv Wien 1932a; b).

Čtyři měsíce intenzivních bojů v zimních Karpatech ukončil průlom německých a rakouských armád u Gorlic 2. 5. 1915, který donutil již o několik dní později jednotky ruské 3. armády (která mezitím frontový úsek u Medzilaborců převzala) zahájit stahování z Karpat. Divize ruského XII. armádního sboru dosáhly v rámci tohoto ústupu 5.5. provizorní obran- né linie, opřené o takticky významnou výšinu Weretyszów/Veretyčiv (dle dobových map kóta 742, podle současného měření 741,9 m n. m.), na které se dočasně opevnily. Jejich pronásledovatelem byl rakousko-uherský VII. armádní sbor, jehož 20. honvdéská pěší divize dosáhla 6. 5. 1915 vesnice Habura, odkud měla následujícího dne pokračovat v postupu přes hlavní karpatský hřeben směrem na Wisłok Wielky (Kriegsarchiv Wien 1932b; Rózsafi 2017). https:// nagyhaboru.blog.hu/2017/05/18/gyozelem_minden_aron).

Útočící vojáci 17. honvédského pěšího pluku (doplňovací obvod Székesfehérvár v dnešním Mad’arsku) v brzkých ranní hodinách narazili na narychlo vybudovanou ruskou obrannou 
linii na okraji lesa na kótě Veretyčiv. Př́ístup $\mathrm{k}$ nim vedl přes poměrně strmý svah, který byl z velké části holý, a nenabízel útočníkům možnost krytí; jakmile útočící vojáci vstoupili do otevřeného terénu, stali se snadným cílem palby z pušek i kulometů obránců. Proto bylo těžiště útoku přeneseno na levé křridlo divize, kde měl 4. honvédský pěší pluk (doplňovací obvod Nagyvárd, dnes Oradea v Rumunsku) dobýt kótu 704 (dnes vrch Łan, cca 712 m n. m.) několik set metrů severně od Veretyčiva; ani on však neuspěl. Vojáci obou pluků pak strávili většinu dne ve svých exponovaných pozicích pod ruskou obrannou linií, vystaveni nejen palbě z ní, ale také ostřelování ruským dělostřelectvem z vesnice Jasieł (dnes zaniklá obec v údolí severovýchodně od Veretyčiva). I přes to, že během dne byla útočná skupina posílena ještě vojáky dalších dvou pluků, cíle se jí podařilo dosáhnout až kolem 20. hodiny večer, poté co ruské oddíly vyklidily nejdříve kótu 704 a pak samotný vrch Veretyčiv v rámci pokračujícího celkového ústupu své armády. Útočící jednotky přišly během celého dne marných pokusů při útoku proti Veretyčivu na kótě 704 o více než 100 vojáků a dalších několik set raněných mužů (Rozsáfi 2017). (https://nagyhaboru.blog. hu/2017/05/18/gyozelem_minden_aron).

\section{Popis lokality}

Vrch Veretyčiv je vzdálen necelé 4 kilometry severovýchodně od obce Habura v okrese Medzilaborce. Jedná se o hraniční vrchol vysoký 741,9 m n. m., který je součástí Laborecké vrchoviny spadající pod Východní Karpaty. Od námi dřive zkoumaných lokalit se Veretyčiv poměrně zásadně odlišuje rozsahem lesního porostu - na rozdíl od hustě zalesněných vrchů Kobyla a Staviská je na Veretyčivu les pouze v úzkém pásu podél státní hranice. V blízkosti vrcholu se pak nachází velké nezalesněné plochy sloužící dlouhodobě jako pastviny. Lokalita a její blízké okolí je poměrně dobře dochována do dnešní doby, není př́liš narušená zemědělstvím ani lesnictvím. Přesto se nám podařilo zaznamenat poničení menší části polní fortifikace, ke kterému došlo mezi naší první a druhou návštěvou lokality.

Poblíž vrcholu, ještě v zalesněné části, se nachází ruské opevnění, sestávající z řady mělkých okopů, sloužících jako okopy pro klečícího či ležícího střelce. V některých případech dochované relikty okopů naznačují, že vojáci začali tyto jednotlivé pozice vzájemně propojovat do zákopové linie, nicméně na mnoha místech práce nebyly dokončeny. Opevnění je orientováno směrem k pastvině, která začíná nedaleko, což nahrávalo úspěšnému provedení detektorové prospekce.

\section{Metoda výzkumu}

Metoda průzkumu novověkých bojišt detektorem kovů často spočívá v zásadě v namátkovém detektorování zájmového území, lokalizovaného pomocí archivního bádání, a pečlivého zaměření nalezených artefaktů. Tento přístup zvolil Thomas J. Nolan při jednom z mála průzkumů moderního bojiště, již zmíněné hlídky Alvina C. Yorka z roku 1918. Při prospekci v terénu se kromě archivních materiálů orientoval podle historického příkopu oddělujícího soukromý pozemek od obecního lesa. K zaznamenávání pozic artefaktů byl využíván přístroj GPS (Nolan 2009, 84-90). Stejně postupoval i Matouš Holas při průzkumu bojiště u Náchoda (Holas 2017, 18-19). Do jisté míry podobný namátkový průzkum provedl Tony Pollard při výzkumu zákopů u Mont St Quentin. Výzkum prostor před zákopy byl limitován lesním porostem, který vymezoval volný prostor o šířce 12 metrů a délce 50 metrů; přesto v něm bylo několik stromů a hustě zarostlých míst (Pollard 


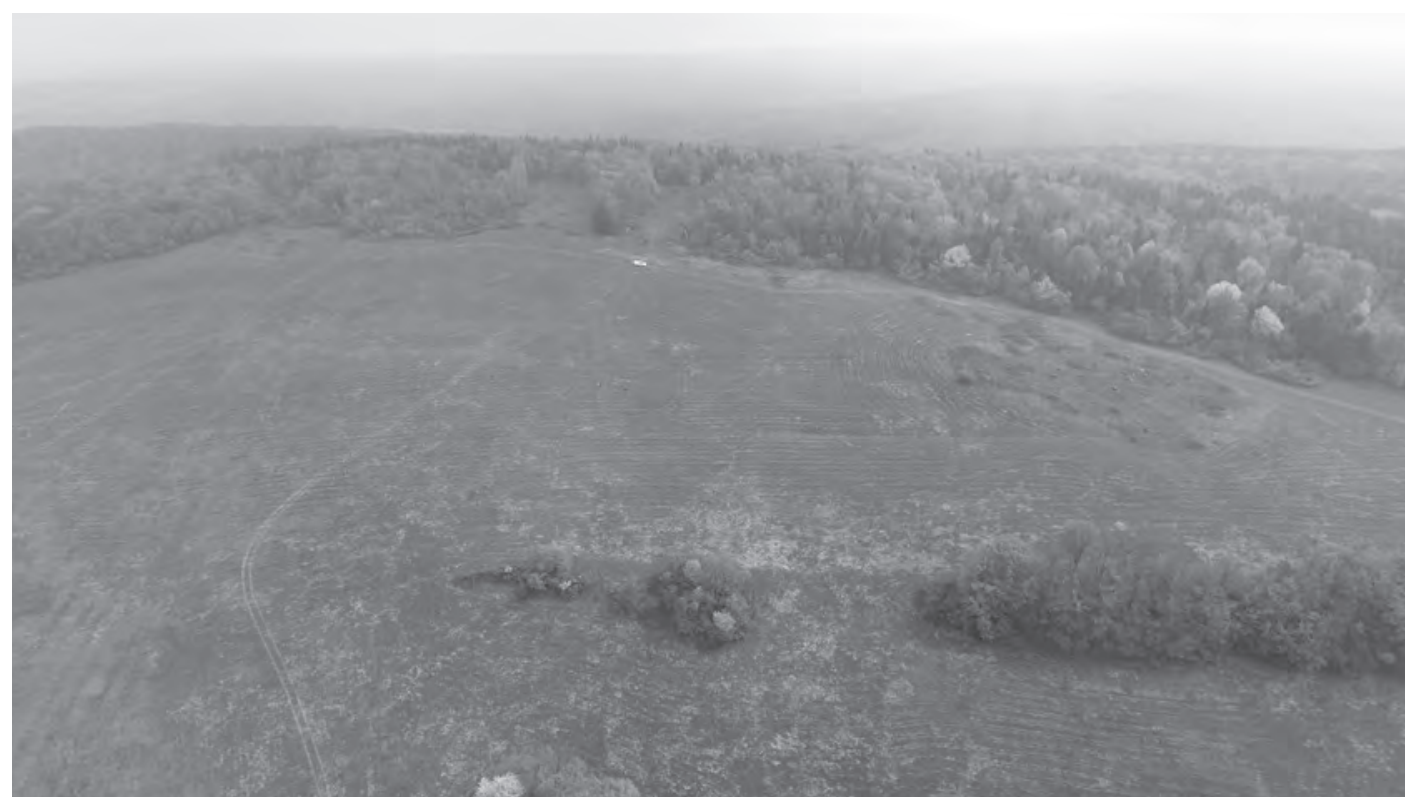

Obr. 2. Veretyčiv. Letecký pohled na lokalitu. V prostoru zalesněného hřebene se nacházely ruské pozice, z jihu přes travnatou pláň útočili honvédští vojáci. Foto: Arpád Balogh. Archiv Technická univerzita v Košicích.

Fig. 2. Veretyčiv. Aerial view of the site. Russian positions were situated in the area of the forested ridge, Honvéd soldiers launched attack from the south through the grassland. Photo: Arpád Balogh. Archive of the Technical University of Košice.

2014, 190). Naopak rozsah prospekce bojiště na Bílé Hoře byl určen na základě stavebních aktivit, které vymezily šest různě velkých polygonů nepravidelných tvarů (Bureš - Rytír 2017, 245-246). Jiný princip definice zkoumaného území byl využit při výzkumech bojišt u řeky Boyne a u Ridgefieldu. V obou případech byly vytyčeny polygony - v prvním případě se jednalo o pět polygonů různé velikosti a tvarů, u Ridgefieldu byly vybrány čtyři čtvercové polygony o délce strany $6,1 \mathrm{~m}$ (Brady - Byrnes - Cooney - O’Sullivan 2007, 62, 69; Silliman Batt 2015, 187).

Zvolená metoda detektorové prospekce na lokalitě Veretyčiv se od většiny výše uvedených příkladů odlišuje. Prvním krokem, odehrávajícím se během jara 2017, bylo seznámení se s lokalitou, které spočívalo v předstihové detektorové prospekci, která začala na úrovni ruských okopů a poté pokračovala kolmo na vrstevnici ve směru, ze kterého přišel honvédský útok. Tímto postupem se podařilo prokázat přítomnost artefaktů dokládajících útok a rovněž získat rámcovou představu o umístění těchto artefaktů v terénu, resp. jejich vzdálenosti od ruských pozic.

V návaznosti na výsledky první etapy bylo přistoupeno ke druhé, která proběhla na podzim 2017. Na vytipovaném místě byl vytyčen polygon o rozměrech $25 \times 50$ metrů, který byl později díky příhodným podmínkám rozšířen o druhý sousedící polygon o stejných rozměrech, díky čemuž dosáhla prozkoumána plocha celkových rozměrů $50 \times 50$ metrů. Polygony byly svou delší osou orientovány kolmo na průběh vrstevnic v prostoru výskytu nejintenzivnějších kovových signálů, přibližně 150 až 200 metrů od ruských pozic. K průzkumu v rámci polygonové sítě 


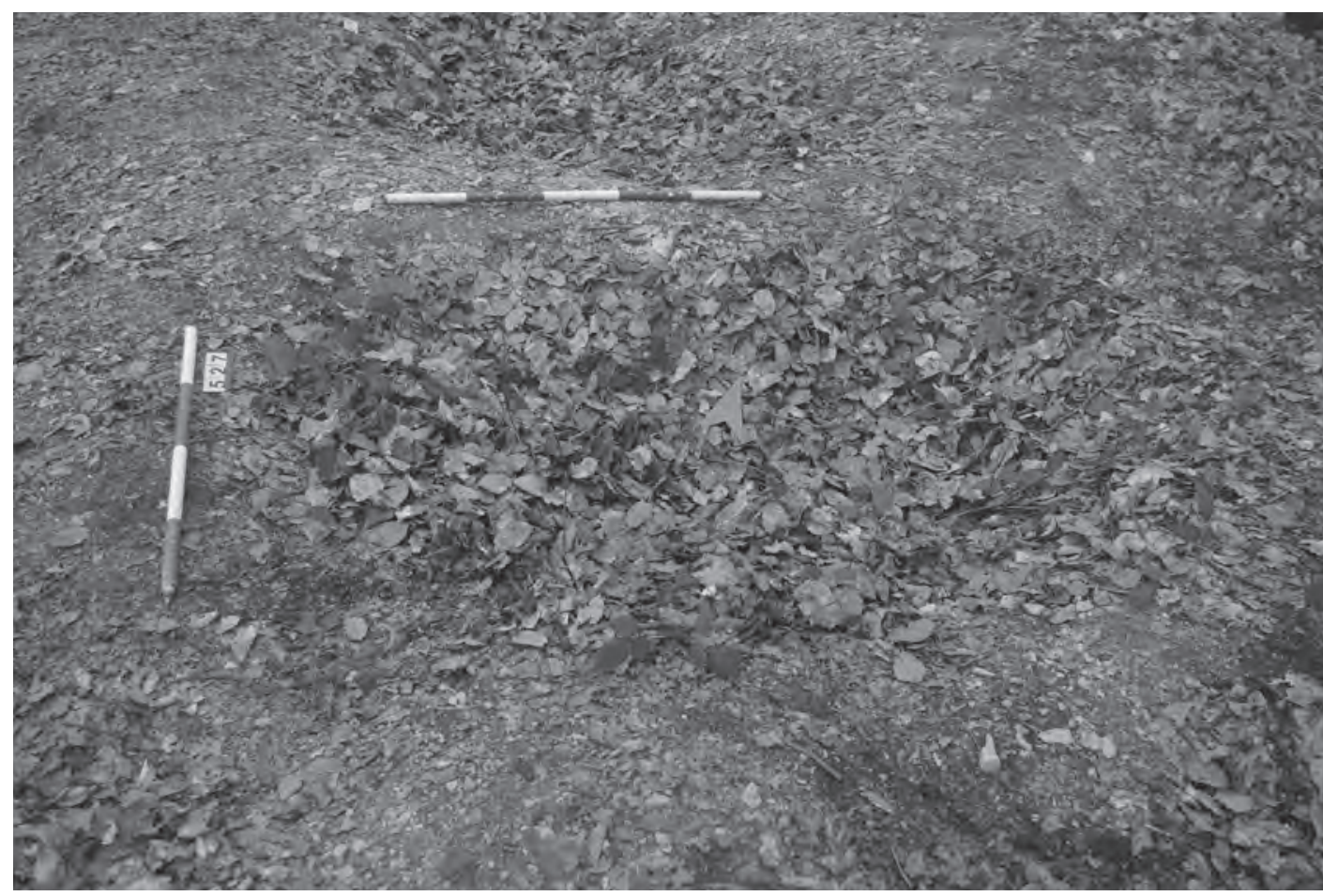

Obr. 3. Veretyčiv. Ruský okop pro jednoho ležícího či klečicího střelce. Foto: Jiří Zubalík.

Fig. 3. Veretyčiv. Russian shell scrape for a single gunman lying down or kneeling. Photo: Jiř́ Zubalík.

bylo přistoupeno především z časových důvodů - prospekce celé plochy by byla časově velmi náročná, zatímco průzkum v rámci vytyčených polygonů přesně ohraničoval zkoumanou plochu a zároveň umožňuje plynule pokračovat v práci i v budoucnu. K detekci byl použit přístroj Golden Mask GM4 Pro s 2D cívkou o průměru 30 cm, která zaručuje dostatečný hloubkový dosah při zachování maximální citlivosti na malé cíle. Při lokalizaci byla využita metoda pohybu v relativně úzkých pásech o šířce $1 \mathrm{~m}$ kolmo na směr útoku, díky čemuž byly dohledány všechny signály v polygonech. Pozice každého artefaktu byla zaznamenána pomocí totální stanice. Samotné vyhodnocení výsledku průzkumu se provedlo v prostředí geografických informačních systémů, ve kterém byla sledována prostorová distribuce dokumentovaných artefaktů.

\section{Výsledky výzkumu}

Nálezový soubor získaný z detektorové prospekce čítá 176 kusů artefaktů. Ty lze podle jejich původu rozdělit do tří hlavních kategorií:

1. doklady dělostřeleckého ostřelování;

2. artefakty patřící útočícím vojákům rakousko-uherské armády;

3. nálezy související s recentní lidskou aktivitou.

Nejčetněji jsou zastoupeny nálezy spojené s útočícími honvédskými vojáky. Patří sem 120 kusů vystřelených nábojnic do pušky Mannlicher M95 8 × 50R (obr. 4:2), 2 vystřelené (případně vypadnuté) projektily Mannlicher $8 \times 50 \mathrm{R}$ (obr. 4:1), jeden rámeček na náboje a pravděpodobně jeden exemplář čištění (vytěrák) na 

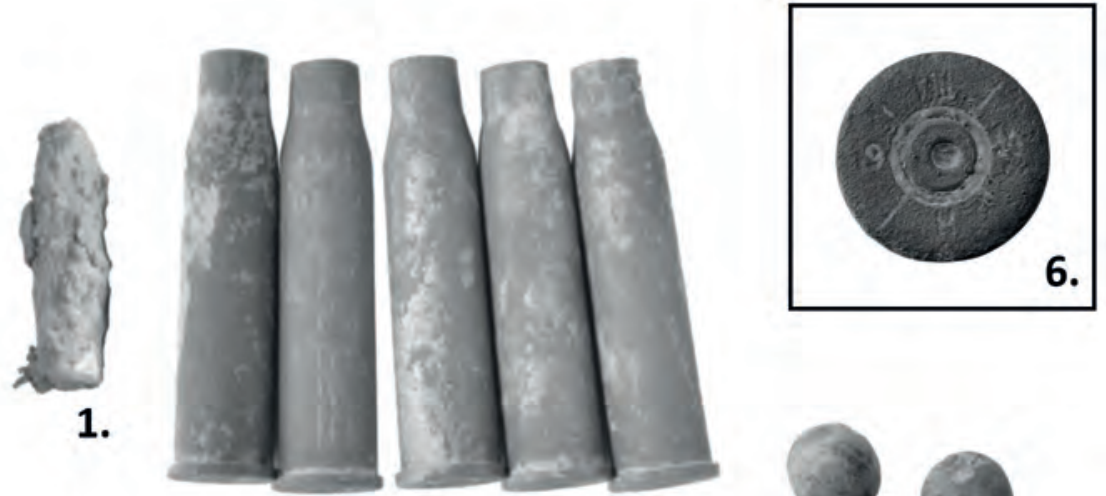

2.

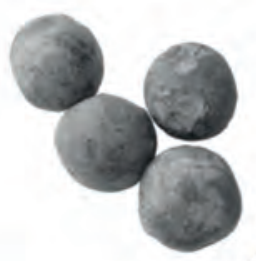

3.
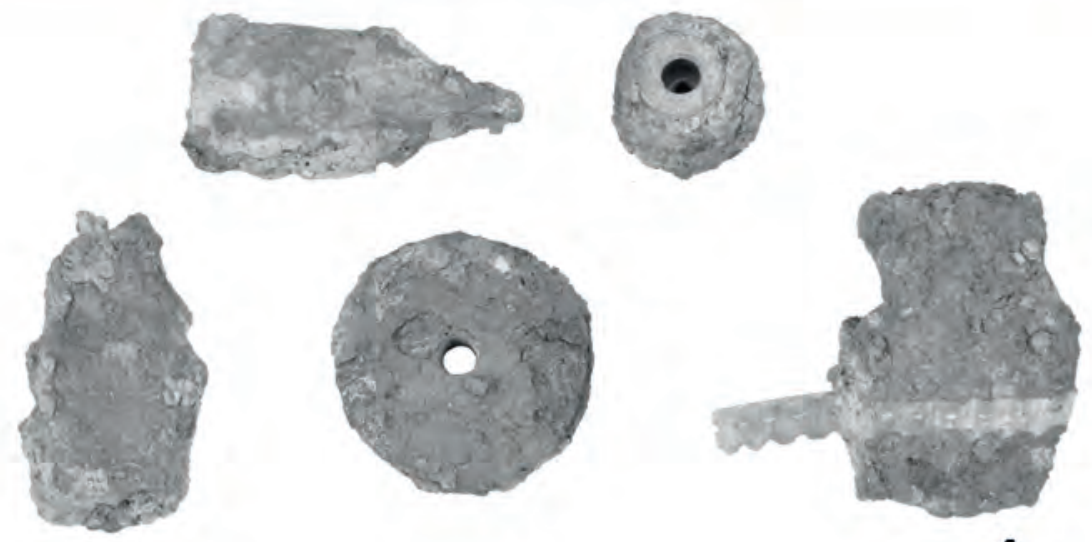

4.

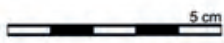

5.

Obr. 4. Veretyčiv. Nálezy z lokality: 1. projektil Mannlicher $8 \times 50 R$, 2. nábojnice Mannlicher $8 \times 50 R$, 3. olověné projektily ze šrapnelů, 4. střepiny dělostřeleckých granátů, kruhová výmetnice a olověné projektily ze šrapnelu, dno granátu s vodící obroučkou, 5. čištění pušky, 6. detail dnové ražby na nábojnici Mannlicher $8 \times 50 R$. Foto: Jakub Těsnohlídek.

Fig. 4. Veretyčiv. Finds from the site: 1 . Mannlicher $8 \times 50$ R projectile, 2. Mannlicher $8 \times 50 R$ cartridge, 3. lead projectiles from shrapnel shells, 4 . fragments of artillery shells, 5 . barrel cleaner, 6 . headstamp on a Mannlicher $8 \times 50 R$ cartridge. Photo: Jakub Těsnohlídek. 


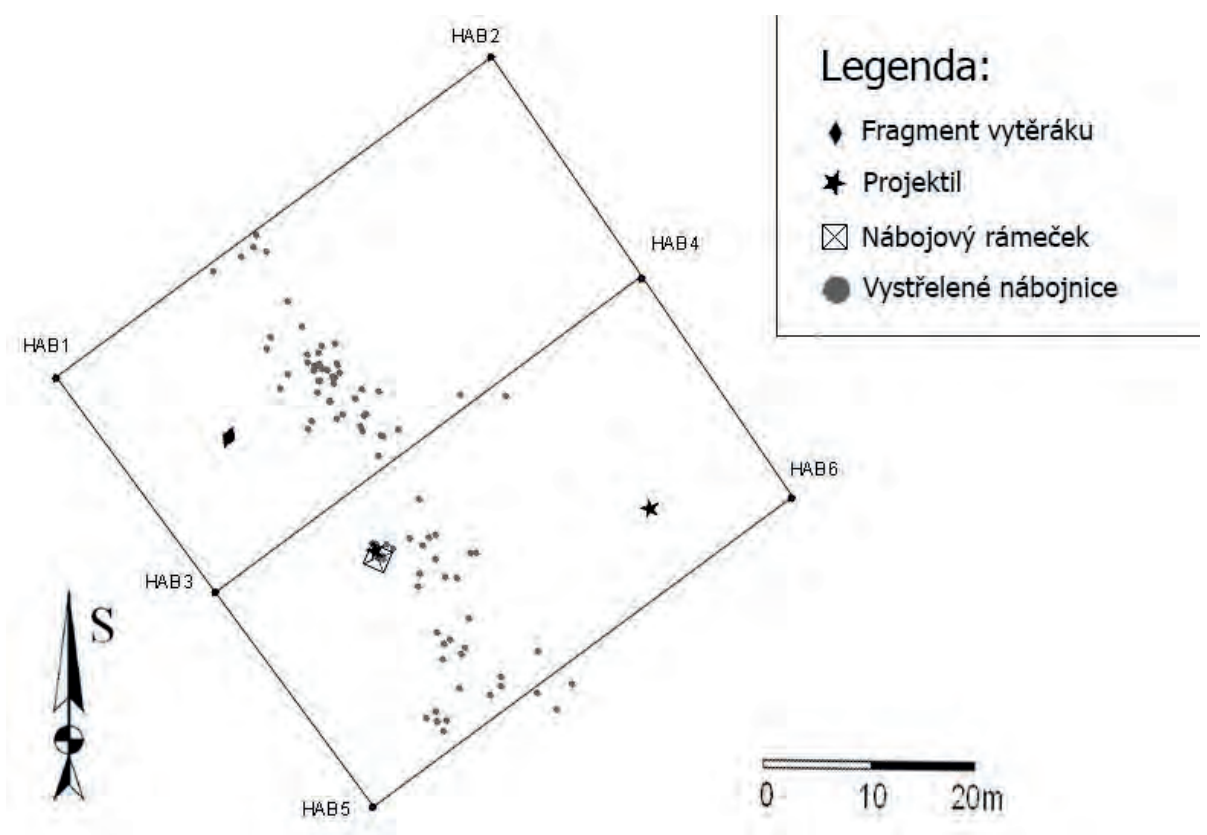

Obr. 5. Veretyčiv. Distribuce pěchotní munice a vybavení. Autor: Martin Fojtík.

Fig. 5. Veretyčiv. Distribution of infantry ammunition and equipment. Author: Martin Fojtík.

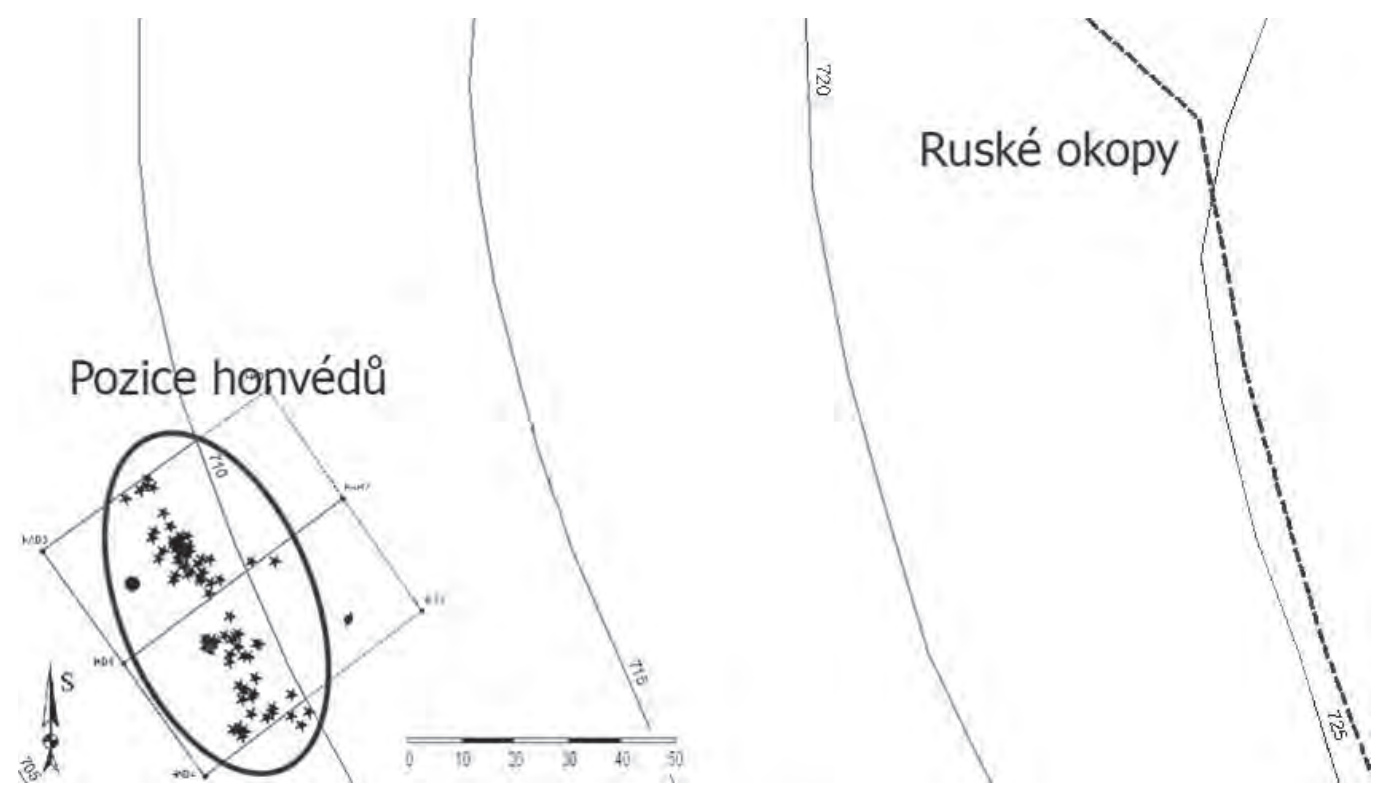

Obr. 6. Veretyčiv. Prostorový vztah mezi distribucí pěchotní munice a přibližným umístěním okopů. Autor: Martin Fojtík.

Fig. 6. Veretyčiv. Spatial relationship between the distribution of infantry ammunition and the supposed position of shell scrapes. Author: Martin Fojtík. 


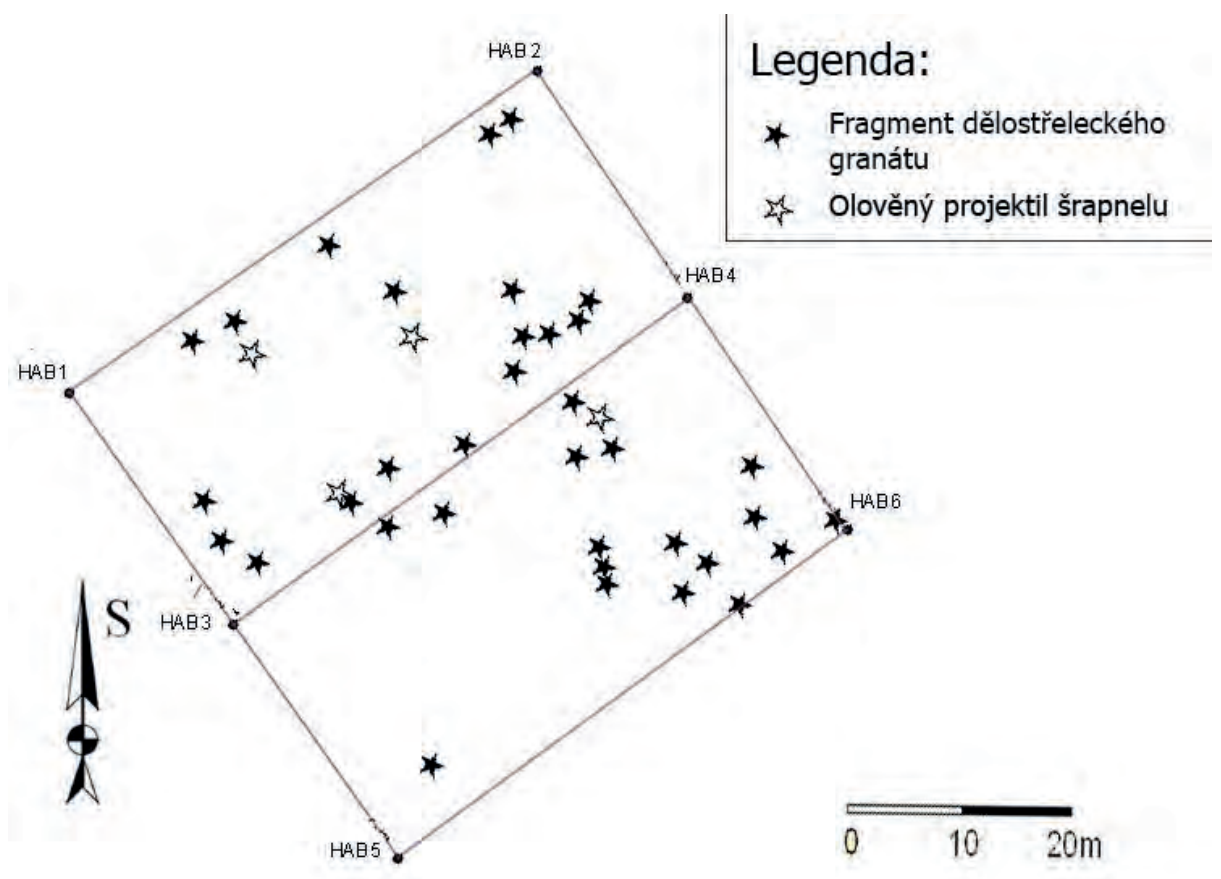

Obr. 7. Veretyčiv. Distribuce fragmentů dělostřelecké munice. Autor: Martin Fojtík.

Fig. 7. Veretyčiv. Distribution of artillery ammunition fragments. Author: Martin Fojtík.

pušku (obr. 4:5). V jednom případě jsme zaznamenali i předmět nevojenského charakteru - minci. Její špatný stav prozatím neumožňuje přesné určení. Na několika exemplářích nábojnic byl ověřen rok výroby 1914 a rakouský výrobce z Hirtenbergu (obr. 4:6). Všechny tyto artefakty se v rámci polygonů vyskytují v lineární koncentraci (obr. 5). Lze také říct, že honvédi využili pro útok terénní zlom, který je od linie ruských obránců vzdálen zhruba 170 metrů při převýšení 15 až 20 metrů (obr. 6).

Druhou nejčastější kategorií jsou artefakty dokládající dělostřelecké ostřelování, kam řadíme nálezy 35 fragmentů dělostřeleckých granátů (z toho jeden kus výmetnice ${ }^{1}$ a jeden zlomek dna s vodící obroučkou ${ }^{2}$, obr. 4:4) a 4 olověné projektily ze šrapnelů (obr 4:3). Prostorová distribuce zahrnuje celou plochu vytyčených poly- gonů, čímž se překrývá i s objevenými pozicemi honvédů (obr. 7).

Díky značné odlehlosti a nedostupnosti nebyla lokalita nijak výrazně zamořena kovovým odpadem. Nálezový celek doplňuje pouze 9 recentních artefaktů souvisejících s lesní těžbou, případně zemědělskou činností a 3 artefakty, které evidujeme jako drobné neurčitelné ocelové úlomky.

\section{Diskuse}

Výsledky detektorového průzkumu umožňují určit místo, ze kterého vedli palbu honvédští vojáci na opevněné ruské pozice. Tento typ informace při "tradičním” výzkumu polních fortifikací často chybí. Tyto výzkumy přinášejí 
nejčastěji poznatky o životě v zákopech, v nálezových souborech se často objevují plechovky od jídla, mince, knoflíky apod., doplněné o doklady dělostřelecké prrípravy a pěchotní munici, at' už nevystř́lenou nebo vystř́lenou, svědčící o obranné palbě obránců (např. Gonzáles-Ruibal, 2011, 104-110; Pollard 2014, 189). Jednou z výjimek je průzkum Thomase J. Nolana u Châtel-Chéhéry, který dokázal lokalizovat místo, odkud vedl ze své pistole palbu Alvin C. York na německé kulometné hnízdo vzdálené zhruba 60 metrů (Nolan 2009, 93-97). Evidenci bojů, podobnou situaci pod vrchem Veretyčiv, zaznamenal Tony Pollard při průzkumu předpolí německého zákopu na Mont St. Quentin, na který útočili v srpnu 1917 australští vojáci. Ve vzdálenosti 50 metrů od zákopu se podařilo vyzvednout několik australských nábojnic a dokonce i několik německých, svědčících o lokálním protiútoku. Na celé zkoumané ploše se pak nacházely doklady dělostřelecké přípravy - střepiny dělostřeleckých granátů, šrapnely apod. (Pollard 2014, 195)

Vzhledem k jednorázovému charakteru bojové události obsahuje získaný nálezový soubor z Veretyčivu důležité informace pro srovnání s ostatními lokalitami zkoumanými na severovýchodním Slovensku. Pozoruhodné je srovnání s lokalitou na vrchu Kobyla u Výravy (okr. Medzilaborce), která byla místem těžkých několikadenních střetů, během kterých změnil vrchol několikrát majitele. Detektorové prospekci na Kobyle byla podrobena skupina zahloubených objektů nacházející se za rakousko-uherskou linií o ploše zhruba $20 \times 30$ metrů; jedná se o plochu přibližně dvakrát menší než jsou zkoumané polygony na Veretyčivu. O výrazně větší intenzitě pěchotních bojů a také o delším pobytu vojáků na Kobyle svědčí vyšší počet munice, která převyšuje počet 200 kusů, zastoupena byla munice všech bojujících stran. Zajímavé výsledky přináší srovnání dokladů dělostřelecké přípravy. Během prospekce bylo dokumentová- no pouze 12 střepin dělostřeleckých granátů, ale naopak dokonce 13 olověných projektilů ze šrapnelů. Pokud se podařilo určit provenienci artefaktů, jednalo se převážně o ruskou munici (Zubalik et al. 2017b, 552). Na základě rozdílných poměrů střepin a projektilů na obou lokalitách je možno usuzovat na rozdílnou taktiku dělostřeleckého ostřelování, tento předpoklad by ale potvrdil šířeji pojatý průzkum na obou lokalitách.

Další srovnání z dosud zkoumaných lokalit nabízí pozice na vrchu Staviská u Stebnické Huty (okr. Bardejov). Zde vojáci rakousko-uherské monarchie drželi pozice po celý měsíc, kdy proti nim nebyl veden žádný útok a mimo potencionální střety předsunutých hlídek tak není dokumentována žádná bojová aktivita. V nálezovém celku je jasně patrný rozdíl v událostech s místem spojenými. Zatímco na Veretyčivu i Kobyle je velké množství vystř́lené pěchotní a dělostřeleckých munice, na Staviskách je pouze pěchotní munice, v drtivé většině nevystř̌elené nábojnice. Rozdíl je dán tím, že na Staviskách nedošlo k bojům. Početné prázdné nábojnice beze stopy úderu do zápalky jsou pak spíše dokladem užití střelného prachu pro rozdělání ohně v chladném horském počasí počínajícího jara (Vojtas 2018, 75).

Shodným prvkem všech lokalit jsou artefakty patřící vojákům, které zde zapomněli, ztratili, nebo z jiného důvodu zanechali. Takovým př́ikladem může být zlomek výtěráku, který se nalezl jak na Veretyčivu, tak i na Staviskách (Vojtas 2018, 76). V prostorové dispozici artefaktů se pak také promítá dějová různorodost. Na Kobyle je hmotná kultura všech tří stran promíchána, nebot se zde bojující strany prostřídaly. Na Staviskách je př́tomna jen v materiálu podunajské monarchie s několika zřejmě kořistními náboji Mosin. Lokalita Habura se vyznačuje prostorovým oddělením obou stran, kdy nedošlo k blízkému kontaktu a je zde možné sledovat postup rakousko-uherských vojáků směrem 
k ruským zákopům, linii palby a prostory zasažené dělostřeleckou palbou.

\section{Závěr}

Prezentované výsledky jsou dílčím příspěvkem k poznáním událostí na lokalitě. Bádání může pokračovat mnoha směry. V současné době jsou vyhodnocovány výsledky geofyzikální prospekce, které provedli kolegové z Herman Ottó múzeum v Miškolci. Cílem tohoto průzkumu je ověření potenciálu tohoto typu prospekce při zjištování rozsahu palebného pole útočících jednotek. Další možnost skýtá analýza prostorové distribuce vystř́lené munice, která může identifikovat pozice jednotlivých střelců; pomoci v této otázce může i studium otisků úderníků na nábojnicích. Další fáze průzkumu této lokality se zaměří na ruské okopy, které budou kresebně a fotograficky dokumentovány a podrobeny detektorové prospekci, která může napovědět o intenzitě obranné palby. Pro získání uceleného obrazu o celé akci pak připadá v úvahu detektorová prospekce prostor, které jsou ve větší vzdálenosti od ruských pozic, kam se stáhli honvédští vojáci po prvních útocích.

Předložená práce představuje jeden z prvních pokusů o využití archeologických metod při výzkumu konkrétní bojové operace mající krátké trvání (v tomto případě zhruba jeden den), která po sobě nezanechala odraz v podobě povrchových archeologických reliktů. K výzkumu této události byla využita systematická detektorová prospekce. Podařilo se doložit jak místo, ze kterého vedli palbu útočící mad’arští vojáci na ruskou zakopanou armádu, tak i dělostřeleckou přípravu, která samotnému útoku předcházela. Detektorová prospekce se tedy ukázala jako ideální metoda průzkumu, schopná přinést v relativně krátkém čase relevantní výsledky, byt’ jen na krátkém úseku celého bojiště.

1) Výmetnice je součást dělostřeleckého granátu - šrapnelu. Má podobu kruhové desky a odděluje šrapnelové kuličky od výmetné náplně, která před cílem exploduje a vystřelí projektily vpřed.

2) Projektily dělostřeleckých granátů byly vyráběny z oceli. Pro snížení otěru uvnitř hlavně a přenosu rotace na projektil byly opatřeny po svém obvodu páskem z mosazi (obroučka, vodící obroučka). Při výstřelu se do měkkého kovu otisklo šikmé drážkování hlavně. 


\section{Bibliografie}

Brady, C. - Byrnes, E. - Cooney, G. - O'Sullivan, A. 2007: An Archaeological Study of the Battle of the Boyne at Oldbridge, Co Meath. Journal of Conflict Archaeology, Vol. 3, 53-77.

Bureš, M. - Rytî́, R. 2017: Bílá Hora - bojiště třicetileté a studené války. Archaeologia Historica 42/1, 245-259.

Gonzáles-Ruibal, A. 2011: Digging Franco's Trenches: An Archaeological Investigation of Nationalist Position from Spanish Civil War. Journal of Conflict Archaeology, Vol. 6, No. 2, 97-123.

Holas, M. 2017: Detektorový průzkum části náchodského bojiště z roku 1866. Historie a vojenství 2017/1, 18-23.

Kriegsarchiv Wien 1932a: Österreich-Ungarns letzter Krieg 1914 - 1918 (Band 1). Wien: Verl. der Militärwiss.

Kriegsarchiv Wien 1932b: Österreich-Ungarns letzter Krieg 1914 - 1918 (Band 2). Wien: Verl. der Militärwiss.

Lees, W. B. 1998: Archaeology of the Mine Creek Civil War Battlefield. Zpráva pro Kansas State Historical Society. Topeka.

Nolan, T. J. 2009: Geographic Information Science as a Method of Integrating History and Archaeology for Battlefield Interpretation. Journal of Conflict Archaeology, Vol. 5, 81-104.

Vojtas, M. 2018: Rakousko-Uherská zákopová linie na vrchu Staviská (okr. Bardejov) z roku 1915 ve světle archeologického výzkumu. Magisterská diplomová práce obhájena na ÚAM FF MU. https:// is.muni.cz/auth/th/g056d/Vojtas_DP.pdf

Pollard, T. 2014: Taking the Hill: Archaeological Survey and Excavation of German Communication Trenches on the Summit of Mont St. Quentin. Journal of Conflict Archaeology, Vol. 9, No. 3, 177-197.

Rak, M. 2011: Možnosti archeologického poznání novodobých polních fortifikací na příkladu lokality z 30. let 20. století. Archaeologia historica 36/1, 279-288.

Rozsáfi, J. 2017: Győzelem - minden áron? https:// nagyhaboru.blog.hu/2017/05/18/gyozelem_ minden_aron (citováno 22. 3. 2019)

Scott, D. D. 2005: Interpreting Archeology at the Little Bighorn Battlefield National Monument. In: Gulliford, A.: Preserving Western History. Albuquerque: University of New Mexico Press, 20-31.

Silliman, G. W. - Batt, B. 2015: Modelling small-arms projectile distribution on eighteenth- and nineteenth-century battlefield sites. Journal of Conflict Archaeology, Vol. 10, No. 3, 177-191.

Śámal, Z. 2018: Detektorový průzkum - metody, technologie, diskuze. In: V.Matoušek-P.Hrnčiř̌́k-Z. Šámal 2018: Rozvadov 1621: Výzkum bojiště třicetileté války. České Budějovice: Veduta, 97-104.

Zubalik, J. - Petřik, J. - Těsnohlídek, J. - Vojtas, M. Kadlec, J. - Bísko, R. - Fojtik, M. - Kapavik, R. Drobňák, M. - Tajkov, P. - Petr, L. 2017a: Pilotní průzkum Rakousko-Uherské zákopové linie na vrchu Staviská (Severovýchodní Slovensko). In: Láník, J. - Kykal, T. (eds.): Léta do pole okovaná 1914-1918. Svazek II., 1915 - noví nepřátelé, nové výzvy. Praha: Ministerstvo obrany České republiky - VHÚ Praha, 522-534.

Zubalik, J. -Těsnohlidek, J. - Petř̀k, J. - Biško, R. - Vojtas, M. - Kapavik, R. - Petr, L. - Tajkov, P. - Drobňák, M. 2017b: Nedestruktivní průzkum bojiště první světové války na kótě Kobyla (okres Medzilaborce). Archaeologia historica 42/2, 539-559.

Zubalik, J. - Těsnohlídek, J. - Petřik, J. - Biško, R. - Fojtik, M. - Vojtas, M. - Kadlec, J. - Petr, L. - Kapavik, R. - Tajkov, P. - Drobřák, M. 2019: Fortifying the Carpathians: Austro-Hungarian Defences in contemporary Eastern Slovakia. In: Košir, U. - Črešnar, M. - Mlekuž, D. (eds.): Rediscovering the Great War. Archaeology and Enduring Legacies on the Soča and Eastern Fronts. London: Routledge, 109-122. 


\section{Hungarian firing line below the Veretyčiv hill near the municipality of Habura First results from the survey of a World War I battlefield}

In May 1915, soldiers of the 17th Honvéd Regiment attacked the Russian army, who fortified their positions on the Veretyčiv hill (741.9 m ASL) near the municipality of Habura in the Eastern Carpathians, on the territory of what is now Northeast Slovakia (Fig. 1). After one day's battle the Russians finally retreated and the Hungarian troops continued their attack (https://nagyhaboru.blog.hu/2017/05/18/ gyozelem_minden_aron).

The major part of the site is an unforested pasture; forest is only visible in a narrow stripe on the hilltop (Fig. 2). In this stripe we detected relics of Russian foxholes, each of them intended for a single gunman lying down or kneeling (Fig. 3). The place from which Honvéd soldiers have fired on the Russians is supposed down the slope, in the unforested part. With regard to ideal conditions we chose systematic detector survey to identify this place exactly.

The survey was divided into two phases. The first reconnaissance was carried out in the spring of 2017. Trial detector survey was targeted at the area in front of the Russian foxholes. The main objective was to localise the occurrence of metal artefacts. Within the second phase, this place was systematically surveyed with a metal detector in two adjacent polygons sized $25 \times 50 \mathrm{~m}$, whose long axis was oriented perpendicular to the contour lines. The position of detected artefacts was thoroughly surveyed with a total station. The collection of finds from the survey comprises 176 artefacts. Most of them are related to the Honvéd attack, above all to infantry ammunition. Cartridges for the Mannlicher M95 rifle were represented by 120 specimens (Fig. 4:2), in two cases we found a projectile (we cannot identify whether it was fallen out or shot, Fig. 4:1) and in one case an en bloc clip to this rifle was found. A stick-like metal artefact could be interpreted as a barrel cleaner (Fig. 4:5). In the surveyed polygon we also found a coin, but its poor condition does not enable more accurate dating.
Artillery preparation is evidenced by 39 artefacts, among them four lead projectiles from shrapnel shells (Fig. 4:3) and other fragments of artillery shells (Fig. 4:4). The remaining artefacts are represented by more recent objects related to forestry or by unidentifiable small metal fragments. Infantry ammunition was found in a linear concentration about 170 metres away from the Russian foxholes (Fig. 5 and 6), whereas the fragments of artillery shells are distributed almost evenly over the whole surveyed area (Fig. 7). Interesting is a comparison of our find collection with another site on the hill Kobyla near Výrava (Medzilaborce District). Detector survey was carried out on an area of about $20 \times 30 \mathrm{~m}$. It has yielded more than 200 pieces of Austrian, Russian and German infantry ammunition, which indicate a longer stay of soldiers and more intensive fights on the site. Differences can be observed with artillery ammunition, which is mostly of Russian provenance - on the Kobyla hill the lead projectiles from shrapnel shells are more frequent, which might refer to different tactics of artillery fire on the two sites (Zubalík et al. 2017b, 552). Also different is the find collection from the Staviská hill near Bardejov, where no battle has taken place. The collection contains a lot of ammunition but no fragments of artillery shells and lead projectiles from shrapnel shells (Vojtas 2018, 75).

This study represents one of the first attempts of archaeological research on a short-term military operation. With the help of a metal detector we localised the firing position of Hungarian troops and the place of artillery preparation before an attack. Detector survey thus seems to be the ideal method of survey, which can yield relevant results within a relatively short time, although only in a small sector of the whole battlefield. In the end we must express our gratitude to Hungarian historians from the Nagy Háború association, who recommended us to survey the site on the Veretyčiv hill. 


\section{Mgr. Jiři Zubalík}

- Ústav archeologické památkové péče Brno, v. v. i., Kaloudova 30, 61400 Brno, Česká republika zubalik.jiri@gmail.com, zubalik@uapp.cz

\section{Bc. Martin Fojtík}

- Ústav archeologie a muzeologie, Filozofická fakulta, Masarykova univerzita, A. Nováka 1, 60200 Brno, Česká republika martinfojtik@mail.muni.cz

\section{Ing. Radim Kapavík}

• Hranická 12, 75124 Přerov, Česká republika kapavikr@gmail.com

\section{Mgr. Martin Vojtas}

- Ústav archeologie a muzeologie, Filozofická fakulta, Masarykova univerzita, A. Nováka 1, 60200 Brno, Česká republika 215438@mail.muni.cz

\section{Mgr. Jakub Těsnohlídek}

- Archaia Brno, z. ú., pracoviště Jihlava, Židovská 26, 58601 Jihlava, Česká republika j.tesnohlidek@seznam.cz

\section{Mgr. Jan Petřík, Ph.D.}

- Ústav geologických věd, Přrrodovědecká fakulta, Masarykova univerzita, Kotlářská 267/2, 61137 Brno, Česká republika petrik.j@mail.muni.cz

\section{Mgr. Peter Tajkov, Ph.D.}

- Katedra teórie a dejin umenia, Fakulta umení, Technická univerzita v Košicích, Watsonova 4, 04200 Košice, Slovenská republika peter.tajkov@tuke.sk 